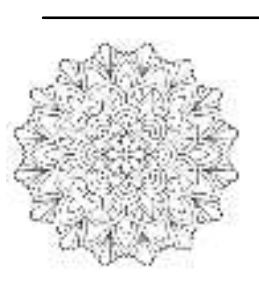

AL HIKMAH: INDONESIAN JOURNAL OF EARLY CHILDHOOD ISLAMIC

EDUCATION

ISSN (P): 2550-2200, ISSN (E): 2550-1100,

VOL. 5 (1), 2021, PP. 1 - 13

http://journal.iaialhikmahtuban.ac.id/index.php/ijecie

\title{
PENERAPAN MODEL PEMBELAJARAN ROLE PLAYING UNTUK MENINGKATKAN KEMAMPUAN BERBAHASA PADA ANAK USIA DINI KELOMPOK B TK KARTIKA VI-15 BIAK
}

\author{
Darlin $^{1}$, Samar ${ }^{2}$, Busyairi Ahmad ${ }^{3}$ \\ ${ }^{13}$ Program Studi Sosiologi, Fakultas Ilmu Sosial dan Ilmu Politik, IISIP YAPIS Biak \\ ${ }^{2}$ Program Studi D3 Administrasi Perkantoran, Fakultas Ilmu Administrasi, IISIP YAPIS Biak \\ alfindarlin@gmail.com \\ Abstrak \\ Penerapan Model Pembelajaran Role Playing Untuk Meningkatan Kemampuan Berbahasa Pada \\ Anak Usia Dini Kelompok B TK Kartika VI-15 Biak. Tujuan penelitian ini adalah untuk \\ mengetahui meningkatnya kemampuan berbahasa pada anak usia dini kelompok B TK Kartika VI- \\ 15 Biak melalui model pembelajaran Role Playing. Jenis penelitian yang digunakan adalah \\ penelitian tindakan kelas (Classroom Action Research). Dengan peneliti menggunakan Teknik \\ penyampaian data dilakukan melalui: (a) lembar observasi pengamatan; (b) Lembar wawancara \\ kemampuan berbahasa anak; (c) merekam proses pembelajaran yang aktifitas guru dan siswa untuk \\ melihat tingkat kemampuan berbahasa pada anak usia dini. Berdasarkan hasil evaluasi siklus I, \\ sebagian besar anak sudah dapat melaksanakan kegiatan dengan baik, namun belum mencapai \\ indikator yaitu $75 \%$ jika anak memperoleh nilai Berkembang Sesuai Harapan (BSH) dan \\ Berkembang Sangat Baik (BSB). Sedangkan hasil evaluasi siklus II, sebesar 95\% telah dicapai oleh \\ 19 orang anak didik, sehingga secara umum dapat dikatakan bahwa program kegiatan atau \\ rangkaian pelaksanaan pembelajaran dalam meningkatkan kemampuan berbahasa anak melalui \\ model role playing (bermain peran) di TK Kartika VI-15 Biak telah terselesaikan dan mencapai \\ target peneliti yaitu indikator keberhasilan $75 \%$.
}

Kata Kunci: Model pembelajaran, Role Playing, kemampuan berbahasa, anak usia dini

\section{Abstract}

The implementation of Role PlayingLearning Model to improve the Language Skill of Early Chilhood in Grup B class at KartikaVI-15 Kindergarten Biak. The purpose of the research is to know the improvement of the language skill ofearly childhood at Kartika VI-15 Kindergarten Biak by conducting the RolePlaying Learning Model. The research method is Classroom Action Research. The data are collected by: (a) observation sheets; (b) interview of early childhood's language skill; and (c) recording the learning process which is involved the communication the teachers and the learners to know the improvement of early childhood's language skill. Based on the result of the cycle I, most of the early childhood leaners can already do the activity well, however have not reached the indicator percentage which is 75\% that if the early childhood learners reach the score of Growing as Expected and Growing well. While, the result of cycle II evaluation, 95\% has been reached by 19 early childhood learners, therefore general the result showed that program of a series impelementation of learning in improving early childhood's language skill through Role Playing Learning Model in Kartika VI-15 Kindergarten has been completed and achieved the research target which is $75 \%$ of success indicator. Keywords: Learning Model, Role playing, Language Skill, Early Childhood's 
Darlin, Samar, Busyairi Ahmad (Penerapan Model Pembelajaran Role Playing)

PENDAHULUAN

Pendidikan merupakan suatu hal yang universal dalam kehidupan manusia, sehingga pendidikan dapat dijadikan tolak ukur dalam melihat kualitas manusia itu sendiri. Terlebih lagi di era-milenial sakarang ini, perubahan sosial yang begitu cepat juga menjadi tantangan besar bagi kehidupan masyarakat di semua lapisan (Busyairi \& Hamjah, 2020). Berangkat dari perubahan yang terjadi di lingkungan masyarakat yang begitu cepat yang diakibatkan oleh perkembangan teknologi yang begitu canggih, berakibat pada perubahan dalam hal kemampuan dalam hal kemampuan berbahasa.

Kebutuhan akan pendidikan yang baik, yang mampu meningkatkan kualitas, mengembangkan karakter, memberikan keunggulan dan kemampuan berkreasi, semakin dirasakan urgensinya. Otonomi dibidang pendidikan memberikan kesempatan dan wewenang untuk melakukan berbagai inovasi dalam pengembangan dan implementasi kurikulum pembelajaran (Ahmad \& Laha, 2020). Seperti halnya dalam pengembangan kemampuan berbahasa pada siswa di TK Kartika VI-15 Biak.

Kemampuan berbahasa adalah salah satu kemampuan dasar yang harus dimiliki anak agar sukses bersekolah atau pun sukses dalam kehidupannya kelak. Kemampuan berbahasa adalah kemampuan berbicara dan memahami apa yang disampaikan lawan bicara, yang mencakup symbol, gambar, ekspresi, dan sebagainya. Salah satu cara untuk meningkatkan kemampuan berbahasa anak adalah dengan sering berbicara kepada anak dan memberikan kesempatan pada anak untuk berbicara.

Berdasarkan hasil observasi yang dilakukan oleh peneliti di TK Kartika VI-15 Biak kemampuan berbahasa anak didik belum berkembang baik. Sedangkan, aktifitas mengajar guru pada TK Kartika VI-15 Biak selama proses pembelajaran belum sepenuhnya menggunakan strategi pembelajaran model Role Playing untuk meningkatkan kemampuan berbahasa anak didik, sehingga sebagian anak didik cenderung pasif karena belum memahami konsep pembelajaran yang disajikan oleh guru dan pada akhirnya anak didik kesulitan mengaitkan permasalahan dengan konsep didalam kehidupan anak didik sehari-hari. Hal itu disebabkan karena guru mengajar dengan menggunakan model Role Playing pada proses pembelajaran yang berpusat pada guru sehingga kemampuan anak didik dalam menyerap materi pelajaran belum maksimal dengan Kriteria Kelulusan Minimal 75\%.

Untuk mengatasi permasalahan diatas, peneliti mencoba menerapkan strategi pembelajaran model Role Playing pada TK Kartika VI-15 Biak, agar kemampuan berbahasa anak didik berkembang sesuai harapan. Penerapan model Role Playing pada penelitian ini dalam pembelajaran di TK yang selama ini berpusat pada guru, akan diubah strateginya 
Darlin, Samar, Busyairi Ahmad (Penerapan Model Pembelajaran Role Playing)

dengan berkolaborasi antara anak didik dan guru sehingga kegiatan pembelajaran tidak berpusat lagi pada guru. Dengan menggunakan model Role Playing pada kegiatan pembelajaran yang bervariasi dapat dilakukan pada aktifitas bermain sambil belajar dan menggunakan pendekatan tematik.

Berdasarkan hal diatas, maka rumusan masalah dalam penelitian ini adalah "Bagaimana penerapan model pembelajaran Role Playing untuk meningkatkan kemampuan berbahasa pada anak usia dini Kelompok B TK Kartika VI-15 Biak ”. Dengan tujuan penelitian adalah untuk mengetahui meningkatnya kemampuan berbahasa pada anak usia dini kelompok B TK Kartika VI-15 Biak melalui model pembelajaran Role Playing.

Menurut Soegeng Santoso (2007:3.5) bahwa pendidikan sebaiknya mengikuti sifatsifat bawaan anak. Dasar pendidikannya merupakan panduan yang serasi antara nature dan pendidikan yang praktis. Pendidikan adalah pengaruh dari pancaindra dan melalui pengalamannya, potensi yang dimiliki dapat dikembangkan.

Menurut Siti Aysiah, dkk (2008:4.1) usia dini seorang anak seringkali dikatakan sebagai usia emas (golden age). Pada masa ini seorang anak memiliki potensi yang sangat besar untuk mengoptimalkan seluruh aspek perkembangan yang ada pada dirinya, seperti perkembangan bahasa, fisik dan motorik, dan lain-lain.

Menurut Pendidik dan ahli Psikologi, bermain merupakan pekerjaan masa kanak-kanak dan cermin pertumbuhan anak. Bermain merupakan kegiatan yang memberikan kepuasan bagi anak. Melalui kegiatan bermain anak memperoleh pembatasan dan memahami kehidupan. (Moeslihatoen R, 2004: 24). Sedangkan menurut Hildebrand (1986:54), bahwa bermain berarti berlatih, mengeksploitas, merekayasa, mengulang latihan apa pun yang dapat dilakukan untuk mentransformasi secara imajinatif hal-hal yang sama dengan dunia orang dewasa. Pelaksanaan kegiatan bermain terdiri dari tiga kegiatan yaitu: (a) kegiatan prabermain, (b) kegiatan bermain dan (c) kegiatan penutup.

Istilah Role Playing dalam model merupakan dua istilah ganda bagi pembelajaran Role Playing maupun model bermain peran, karena tergolong dalam model pembelajaran simulasi, sehingga didalam pelaksanaannya dapat dilakukan dalam waktu bersamaan dan silih berganti. Model Role Playing mendramatisasikan bentuk tingkah laku dalam hubungan sosial (Sudjana, 2001: 85).

Dalam pelajaran Bahasa Indonesia, kemampuan berbicara siswa dapat direkayasa untuk ditingkatkan melalui model pembelajaran Role Playing, karena Role playing efektif dalam memberikan pemahaman konsep secara luas kepada anak melalui tokoh tertentu yang 
Darlin, Samar, Busyairi Ahmad (Penerapan Model Pembelajaran Role Playing)

diseting dalam situasi tertentu. Hal tersebut dapat meningkatkan rasa sosial siswa terhadap lingkungan dari orang disekitarnya. Bermain peran disebut juga bermain simbolik, pura-pura, falitasi, imajinasi, atau bermain drama.

Bermain peran dipandang sebagai sebuah kekuatan yang menjadi dasar perkembangan daya cipta, tahapan ingatan, kerja sama kelompok, penyerapan kosa kata, konsep hubungan kekeluargaan pengendalian diri, keterampilan spasial, aveksi, dan keterampilan kognisi. Bermain peran memungkinkan anak memproyeksikan dirinya kemasa depan dan menciptakan kembali masa lalu. Kualitas pengalaman main peran tergantung pada beberapa faktor, antara lain; 1) cukup waktu untuk bermain, 2) ruang yang cukup, dan 3) adanya peralatan untuk mendukung bermacam-macam adegan permainan (Sudono, 2000: 76).

Menurut Anggani Sudono (2000: 24) terdapat dua jenis bermain peran, yaitu bermain peran mikro dan makro. Bermain peran Mikro dimaksudkan bahwa anak memainkan peran dengan menggunakan alat bermain berukuran kecil misalnya orang-orangan kecil yang lagi berjual beli. Sedangakn bermain peran Makro, anak secara langsung bermain menjadi tokoh untuk memainkan peran-peran tertentu sesuai dengan tema.

\section{METODE}

Jenis penelitian yang digunakan adalah penelitian tindakan kelas (Classroom Action Research). Penelitian Tindakan Kelas ini, dilakukan dengan menggunakan model Role Playing untuk meningkatkan kemampuan berbahasa anak TK Kartika VI-15 Biak. Subjek dalam penelitian ini adalah guru dengan anak didik pada kelompok B TK Kartika VI-15 Biak melalui model pembelajaran Role Playing untuk meningkatkan kemampuan berbahasa anak, yang berjumlah 20 anak.

Adapun teknik pengumpulan data yang digunakan dalam penelitian ini adalah teknik observasi, wawancara dan dokumentasi. Selanjutnya prosedur dalam penelitian ini menggunakan dua siklus yaitu siklus pertama melakukan perencanaan, Tindakan, pengamatan dan refleksi. Pada siklus kedua akan dilaksanakan jika kemampuan berbahasa anak belum mengalami peningkatan sesuai dengan standar yang telah ditentukan dan dengan melihat kekurangan-kekurangan yang dilakukan oleh peneliti.

Teknik analisis data yang peneliti gunakan adalah deskripsi kualitatif, dalam hal ini, analisis data yang diperoleh dari hasil observasi aktivitas guru dan aktivitas siswa. Sedangkan data aktivitas kemampuan berbahasa anak melalui model Role Playing dan penilaian secara kualitatif atau dengan memberikan nilai dalam bentuk simbol seperti $*=$ Belum Berkembang 
Darlin, Samar, Busyairi Ahmad (Penerapan Model Pembelajaran Role Playing)

$(\mathrm{BB}),{ }^{* *}=$ Mulai Berkembang $(\mathrm{MB}),{ }^{* * *}=$ Berkembang Sesuai Harapan $(\mathrm{BSH}), * * * *=$ Berkembang Sangat Baik (BSB).

Sedangakan analisis deskriptif kuantitatif yaitu, dianalisis dengan melihat hasil tes pada setiap akhir tindakan dengan rumus yang digunakan yaitu sebagai berikut:

a. Seorang siswa dikatakan tuntas belajar secara individual jika siswa tersebut telah memperoleh nilai minimal 65 .

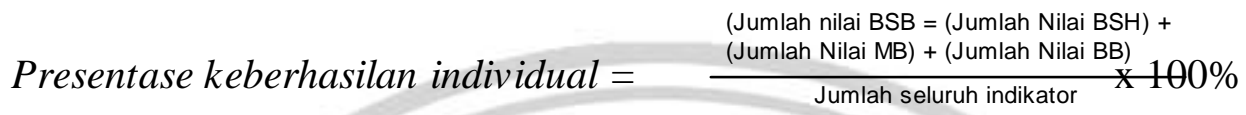

b. Untuk mengetahui presentase ketuntasan belajar anak secara klasikal dengan rumus:

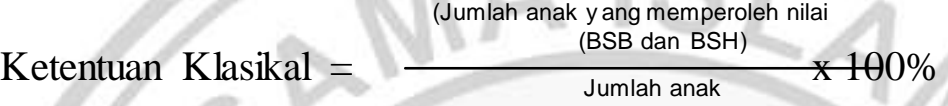

\section{HASIL DAN PEMBAHASAN}

1. Hasil Observasi Aktifitas Mengajar Guru Siuklus II

Hasil analisis observasi guru sesuai dengan lembar observasi sebanyak 18 aspek yang diamati harus dicapai oleh guru. Untuk lebih jelasnya dapat dilihat pada tabel berikut ini:

Tabel 1. Lembar hasil Observasi aktivitas mengajar guru siklus I

No

Aspek yang diamati

\section{Skor}

Siklus I

\section{Kegiatan Awal}

1. Membuka kegiatan pembelajaran dengan mengucapkan salam

2. Guru membimbing anak untuk berdoa sebelum belajar

3. Guru mempersiapkan anak untuk belajar

4. Guru menyampaikan tujuan pembelajaran

5. Melakukan apresepsi yang berhubungan dengan tema pembelajaran

\begin{tabular}{lll} 
6. & Guru memotivasi anak untuk rajin belajar & 1 \\
\hline 7. & Guru menyiapkan media pembelajaran & 1
\end{tabular}

\section{Kegiatan Inti}

8. Guru menjelaskan tujuan pembelajaran/kegiatan yang akan 1 dilaksanakan yang berkaitan dengan model role playing (bermain peran)

9. Guru mencontohkan kepada anak tentang peran yang akan 1 dimainkan

10. Guru membagi tugas kepada setiap anak

11. Guru memandu anak untuk berbagi peran 1 
Darlin, Samar, Busyairi Ahmad (Penerapan Model Pembelajaran Role Playing)

12. Guru mempersilahkan pada anak untuk memainkan peran 0

13. Guru memantau anak dengan berkeliling dalam kelas untuk 1 melihat apakah anak mengerti dan memahami peran yang dimainkan

14. Guru mempersilahkan pada anak untuk menyebutkan media 1 pembelajaran yang akan digunakan

15. Guru membimbing anak dalam kegiatan bermain peran 1

Kegiatan Akhir

16. Guru mengadakan Tanya jawab tentang kegiatan yang dilakukan 0 hari ini

17. Guru memberikan motifasi, penguatan dan penghargaan pada 1 anak

18. Memberikan kesimpulan terhadapkegiatan yang dilakukan hari 1 ini

\begin{tabular}{cr}
\hline Jumlah & 16 \\
\hline Ketercapaian & $\mathbf{8 8 , 8 \%}$ \\
\hline Ketidaktercapaian & $\mathbf{1 1 , 2 \%}$ \\
\hline
\end{tabular}

Dengan demikian persentase dalam kegiatan pembelajaran tercapai $88,8 \%$ dan yang tidak tercapai sebesar $11,2 \%$ dari hasil analisis proses pembelajaran yang dilakukan oleh guru dapat digambarkan dalam histgram berikut ini:

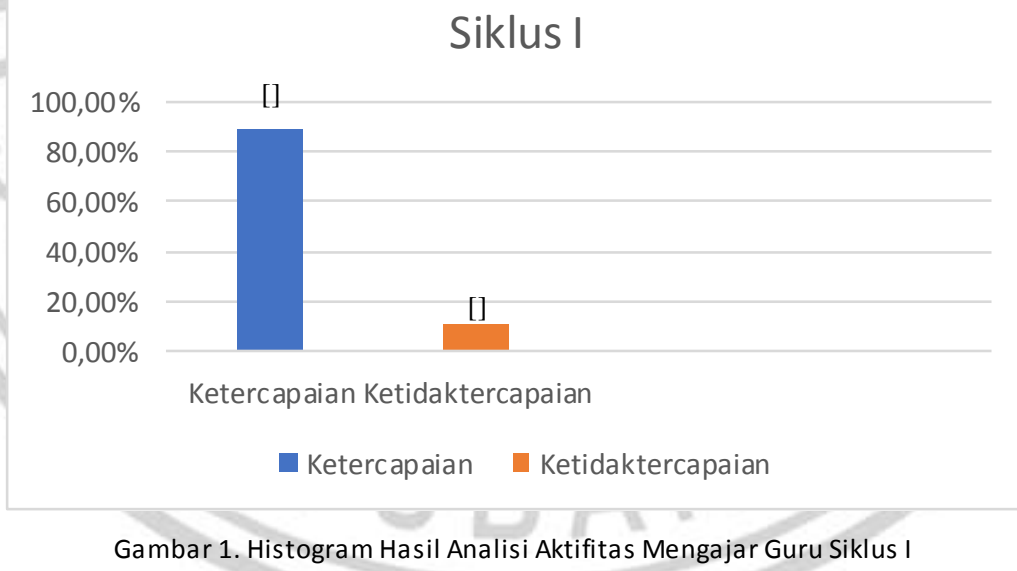

2. Hasil Observasi Aktifitas Belajar Anak Siklus I

Dalam proses pembelajaran siklus I, aktifitas belajar anak yang diamati observer menggunakan lembar observasi aktifitas belajar anak yang terdiri atas 18 aspek. Untuk lebih jelasnya dapat dilihat pada tabel berikut ini :

Tabel 2. Lembar observasi aktifitas belajar anak siklus I

\begin{tabular}{ccc}
\hline No & Aspek yang diamati & Skor \\
\cline { 2 - 2 } & Siklus I \\
\hline
\end{tabular}




\section{Kegiatan Awal}

\begin{tabular}{cll}
\hline 1. & Anak menjawab salam & 1 \\
\hline 2. & Berdoa sebelum belajar dan memimpin doa & 1 \\
\hline 3. & Anak memeprsiapkan diri untuk belajar & 1 \\
\hline 4. & Mendengarkan guru menyampaikan tujuan pembelajaran & 1 \\
\hline 5. & Aktif pada kegiatan apersepsi & 1 \\
\hline 6. & Mendengarkan nasehat yang disampaikan guru & 1 \\
\hline 7. & $\begin{array}{l}\text { Memperhatikan guru saat memeperkenalkan media } \\
\text { pembelajaran }\end{array}$ & 1 \\
\hline
\end{tabular}

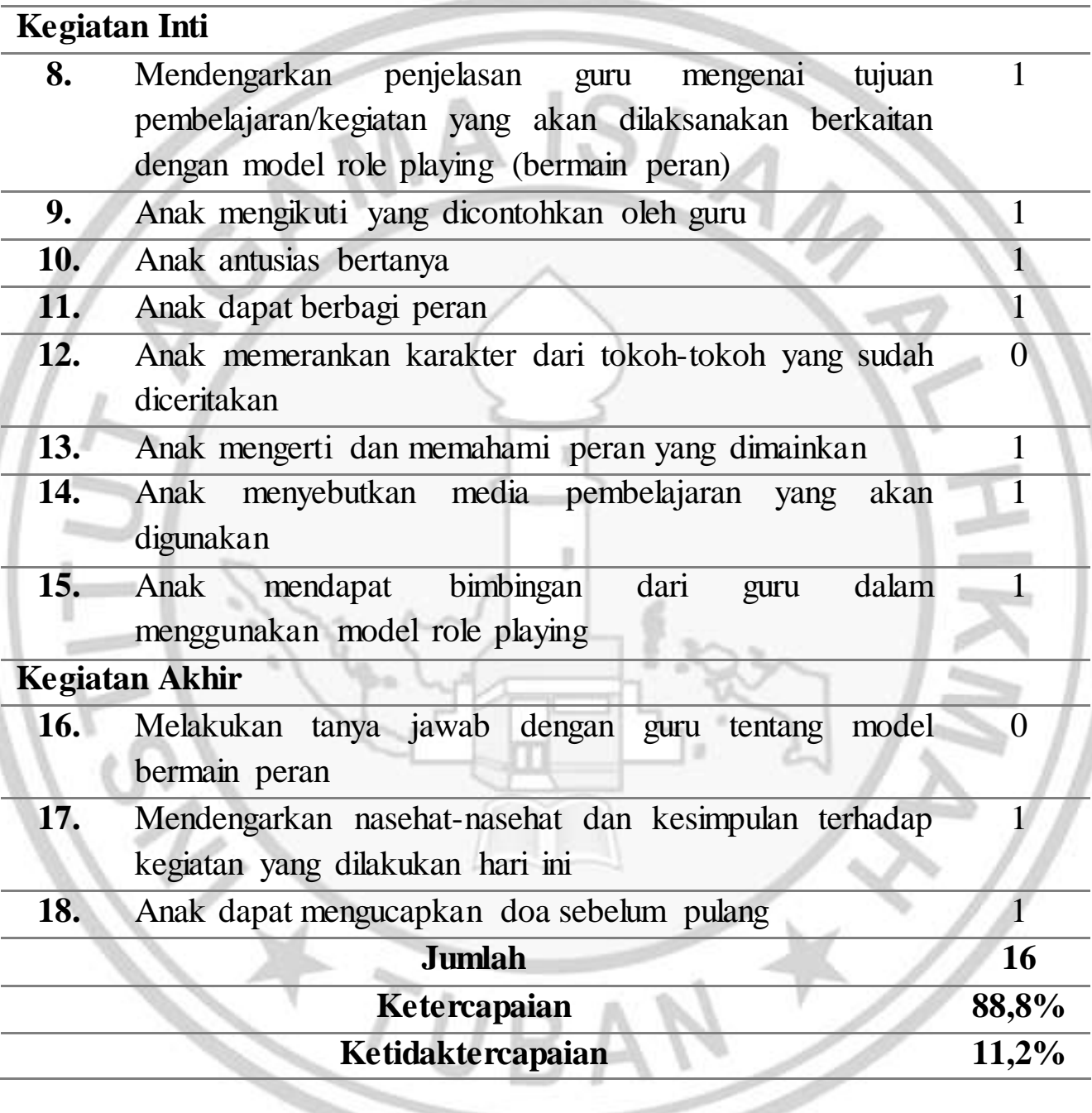

Sumber: Hasil analisis data 2020

Dengan demikian persentase dalam kegiatan pembelajaran tercapai $88,8 \%$ dan yang tidak tercapai sebesar $11,2 \%$.

Tabel 3. Perhitungan Nilai Klasikal pada Tindakan Siklus I

\begin{tabular}{ccc}
\hline Kategori & $\begin{array}{c}\text { Jumlah } \\
\text { Anak }\end{array}$ & Persentase (\%) \\
\hline Berkembang sangat baik (BSB) & 3 & 15 \\
\hline Berkembang Sesuai Harapan (BSH) & 10 & 50 \\
\hline Mulai Berkembang (MB) & 6 & 30 \\
\hline
\end{tabular}


Darlin, Samar, Busyairi Ahmad (Penerapan Model Pembelajaran Role Playing)

\begin{tabular}{lccc}
\hline \hline Belum Berkembang (BB) & 1 & 5 \\
Jumlah & $\mathbf{2 0}$ & $\mathbf{1 0 0}$ \\
\hline Berdasarkan hasil evaluasi tersebut, sebagian besar anak sudah dapat \\
melaksanakan kegiatan dengan baik, namun belum mencapai indikator yaitu $75 \%$ jika \\
anak memperoleh nilai Berkembang & Sesuai Harapan $(\mathrm{BSH})$ dan Berkembang Sangat \\
Baik (BSB).
\end{tabular}

3. Hasil Observasi Aktifitas Mengajar Guru Siuklus II

Hasil analisis observasi guru sesuai dengan lembar observasi sebanyak 18 aspek yang diamati harus dicapai oleh guru, pada siklus II skor yang dicapai oleh guru dari 18 aspek hanya 17 aspek $(94,4 \%)$. Untuk lebih jelasnya dapat dilihat pada table berikut ini:

Tabel 4. Lembar observasi aktifitas mengajar guru siklus II

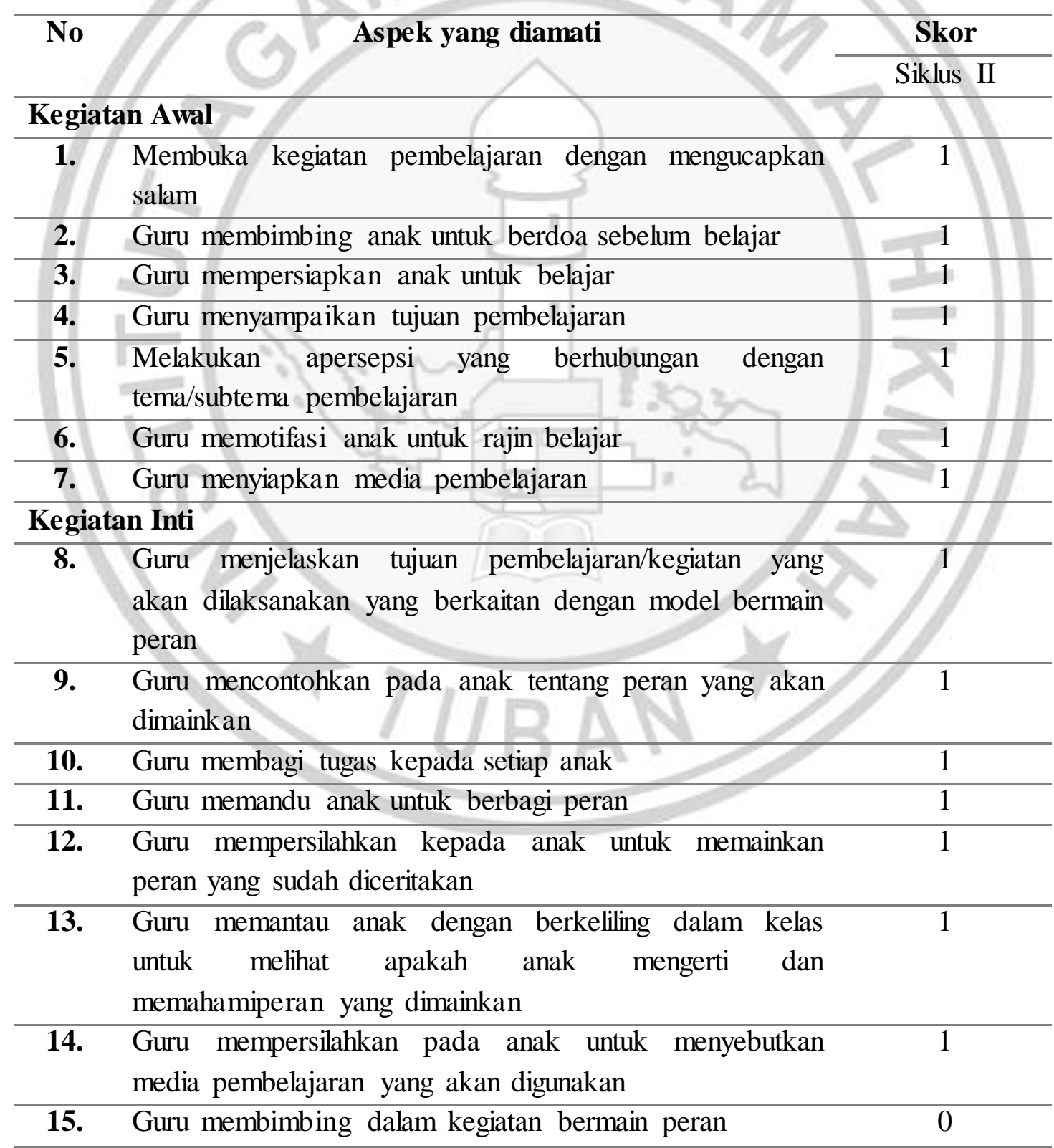

Kegiatan Akhir

8 AL HIKMAH: INDONESIAN JOURNALOF EARLY CHILDHOOD ISLAMIC EDUCATION $\mid$ VOL.5 No.1 Tahun 2021 
Darlin, Samar, Busyairi Ahmad (Penerapan Model Pembelajaran Role Playing)

16. Guru mengadakan tanya jawab tentang kegiatan yang dilakukan hari ini

17. Guru memberikan motifasi, penguatan dan penghargaan 1 pada anak

18. Memberikan kesimpulan terhadap kegiatan yang 1 dilakukan hari ini

\begin{tabular}{cc}
\hline Jumlah & 17 \\
\hline Ketercapaian & $\mathbf{9 4 , 4 \%}$ \\
\hline Ketidaktercapaian & $\mathbf{5 , 6 \%}$
\end{tabular}

Dari data dalam tabel aktifitas mengajar guru pada siklus II menunjukan ada 18 aspek yang diamati dalam proses pembelajaran dan 18 aspek tersebut ada 17 aspek yang terlaksana dan 1 aspek yang tidak terlaksana. Dengan demikian persentase dalam kegiatan pembelajaran tercapai $94,4 \%$ dan yang tidak tercapai sebesar 5,6\%. Dari hasil analisis proses pembelajaranyang dilakukan oleh guru dapat digambarkan dalam histogram berikut ini.

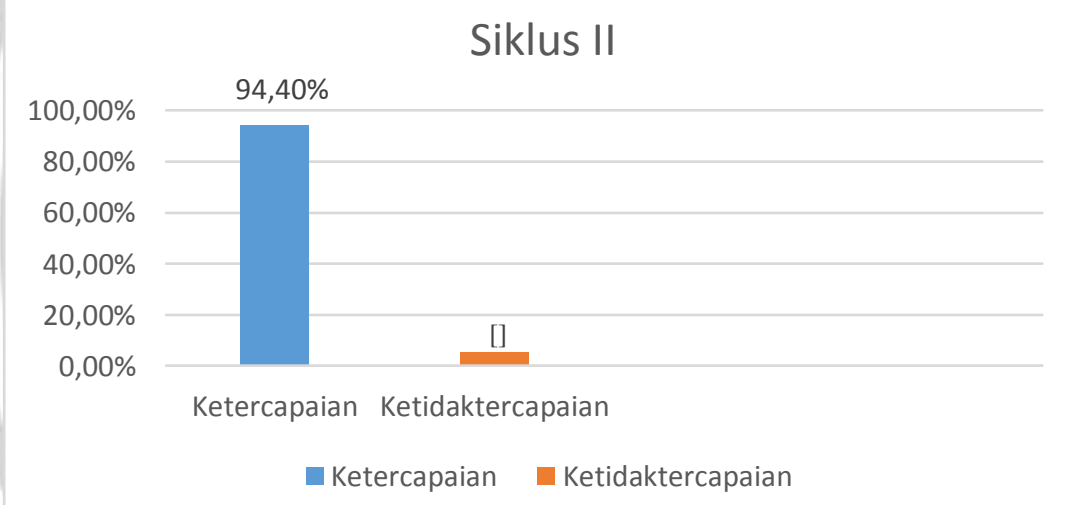

Gambar 2. Histogram Hasil Analisis Aktifitas Mengajar Guru Siklus II

4. Hasil observasi Aktifitas Belajar Anak Siklus II

Dalam proses pembelajaran siklus II, aktifitas belajar anak yang diamati observer menggunakan lembar observasi aktifitas belajar anak yang terdiri atas 18 aspek.

Tabel 5. Lembar observasi aktifitas belajar anak siklus II

\begin{tabular}{llc}
\hline No & \multicolumn{1}{c}{ Aspek yang diamati } & Skor \\
\cline { 2 - 3 } & & Siklus II \\
\hline \multicolumn{2}{l}{ Kegiatan Awal } & 1 \\
\hline 1. & Anak menjawab salam & 1 \\
\hline 2. & Berdoa sebelum belajar dan memimpin doa & 1 \\
\hline 3. & Anak memeprsiapkan diri untuk belajar & 1 \\
\hline 4. & Mendengarkan guru menyampaikan tujuan pembelajaran & 1 \\
\hline 5. & Aktif pada kegiatan apersepsi & 1 \\
\hline 6. & Mendengarkan nasehat yang disampaikan guru & 1 \\
\hline
\end{tabular}


Darlin, Samar, Busyairi Ahmad (Penerapan Model Pembelajaran Role Playing)

7. Memperhatikan guru saat memeperkenalkan media 1 pembelajaran

\section{Kegiatan Inti}

8. Mendengarkan penjelasan guru mengenai tujuan 1 pembelajaran/kegiatan yang akan dilaksanakan berkaitan dengan model role playing (bermain peran)

\begin{tabular}{lll}
\hline 9. Anak mengikuti yang dicontohkan oleh guru & 1 \\
\hline 10. & Anak antusias bertanya & 1 \\
\hline 11. Anak dapat berbagi peran & 1 \\
\hline $\begin{array}{l}\text { 12. Anak memerankan karakter dari tokoh-tokoh yang sudah } \\
\text { diceritakan }\end{array}$ & 0 \\
\hline
\end{tabular}

13. Anak mengerti dan memahami peran yang dimainkan 1

14. Anak menyebutkan media pembelajaran yang akan 1 digunakan

15. Anak mendapat bimbingan dari guru dalam menggunakan 1 model bermain peran

\section{Kegiatan Akhir}

16. Melakukan tanya jawab dengan guru tentang model bermain 0 peran

17. Mendengarkan nasehat-nasehat dan kesimpulan terhadap 1 kegiatan yang dilakukan hari ini

18. Anak dapat mengucapkan doa sebelum pulang Jumlah 17

\section{Ketercapaian} Ketidaktercapaian

Sumber: Hasil analisis data 2020

Dari data dalam table aktifitas belajar anak pada siklus II menunjukan ada 18 aspek yang diamati dalam prose pembelajaran dan 18 aspek tersebut ada 17 aspek yang terlaksana 1 aspek yang tidak dapat terlaksana. Dengan demikian persentase dalam kegiatan pembelajarantercapai $94,4 \%$ dan yang tidak tercapai 5,6\%. analisis keberhasilan tindakan secara klasikal dan diperoleh hasil seperti tampak pada tabel 10 berikut ini:

Tabel 6. Perhitungan Nilai Klasikal pada Tindakan Siklus II

\begin{tabular}{ccc}
\hline Kategori & Jumlah & Persentase (\%) \\
& Anak & \\
\hline Berkembang sangat baik (BSB) & 16 & 80 \\
\hline Berkembang Sesuai Harapan (BSH) & 3 & 15 \\
\hline Mulai Berkembang (MB) & 1 & 5 \\
\hline
\end{tabular}


Darlin, Samar, Busyairi Ahmad (Penerapan Model Pembelajaran Role Playing)

Belum Berkembang (BB) 0

0

Jumlah

20

100

Dengan demikian dapat dikatakan bahwa sebagian anak didik dipandang telah mampu menyelesaikan tugas-tugas yang telah ditetapkan sesuai dengan indikator penilaian dalam peneklitian ini khususnya dalam pelaksanaan tindakan siklus II. Selain itu, dengan perolehan nilai sebesar 95\% tersebut telah dicapai ileh 19 norang anak didik, sehingga secara umum dapat dikatakan bahwa program kegiatan atau rangkaian pelaksanaan pembelajaran dalam meningkatkan kemampuan berbahasa anak melalui model role playing (bermain peran) di TK Kartika VI-15 Biak telah terselesaikan dan mencapai target peneliti yaitu indikator keberhasilan $75 \%$.

Setelah dilakukan perbaikan-perbaikan dalam siklus II, ternyata hasil yang diperoleh mengalami peningkatan yang cukup signifikan pada aspek kemampuan berbahasa anak. Berdasarkan data yang diperoleh pada siklus I dan siklus II dapat diketahui perbandingan jumlah anak yang memiliki kemampuan berbahasa dengan kriteria Berkembang Sangat Baik (BSB) dan Berkembang Sesuai Harapan (BSH), sebelum tindakan atau observasi awal sebanyak 9 anak dengan persentase 50\%, setelah pelaksanaan siklus I mengalami peningkatan menjadi 13 anak dengan persentase $65 \%$ dan siklus II meningkat lagi menjadi 19 anak dengan persentase 95\%.

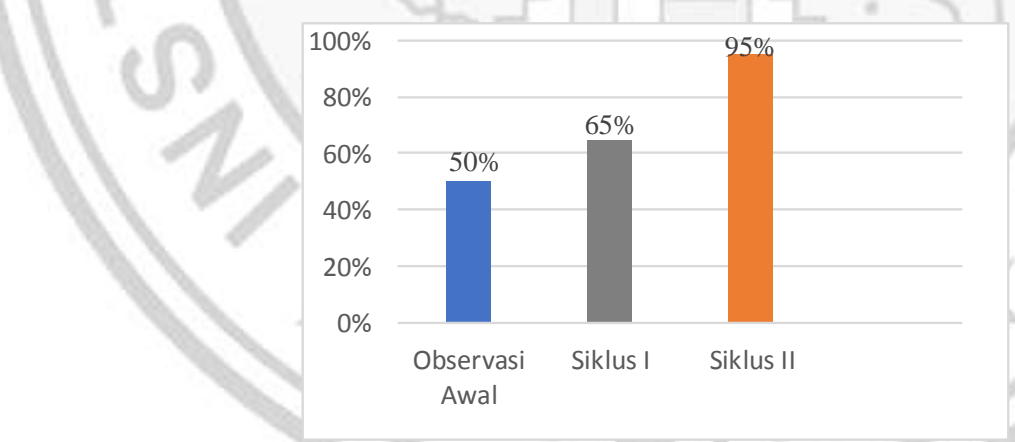

Gambar 3. Histogram hasil analisis kemampuan berbahasa anak melalui model role playing (bermain peran)

\section{PENUTUP}

\section{Simpulan}

Berdasarkan hasil penelitian yang dilakukan selama dua siklus melalui observasi awal kemampuan berbahasa anak adalah 50\%, pada siklus I meningkat menjadi $65 \%$ dan pada siklus II meningkat lagi menjadi 95\%. Dengan demikian dapat disimpulkan bahwa penerapan 
Darlin, Samar, Busyairi Ahmad (Penerapan Model Pembelajaran Role Playing)

model role playing (bermain peran) dapat meningkatkan kemampuan berbahasa anak di Kelompok B TK Kartika VI-15 Biak.

Saran

Berdasarkan hasil penelitian dan analisis data diatas, maka penulis dalam hal ini memberikan beberapa saran, diantaranya: 1) Kepada Lembaga Pendidikan untuk terus mengembangkan inovasi kurikulum terutama dalam hal peningkatan berbahasa bagi anak didik atau siswa, 2) Kepada orang tua siswa untuk berperan aktif dalam membimbing anakanak terutama dalam hal penggunaan bahawa.

\section{DAFTAR PUSTAKA}

Aisyah, Siti. dkk, (2008). Perkembangan dan Konsep Dasar Anak Usia Dini. Jakarta: Universitas Terbuka.

Alhafidzh, (2010). Role Playing dan Penerapannya. http;//www.wordpress.com.(diakses pada tanggal 5 Januari 2020)

Anwar, dkk, (2007). Pendidikan Anak Usia Dini. Bandung: Alfabeth.

Arikunto, (2006). Prosedur Penelitian Suatu Pendekatan Praktek. Jakarta: Rineka Cipta

Ahmad, B., \& Laha, M. S. (2020). IMPLEMENTATION OF FIELD STUDIES TO IMPROVE PROBLEM ANALYSIS ABILITY (CASE STUDY IN THE STUDENT SOCIOLOGY IISIP

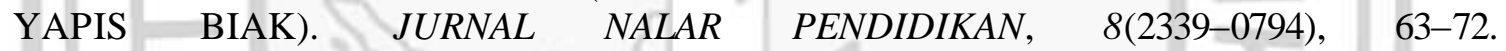
https://doi.org/https://doi.org/10.26858/jnp.v8il.13644

Busyairi, A., \& Hamjah, B. (2020). PERAN LEMBAGA PENDIDIKAN NONFORMAL DALAM MENANGANI KEMISKINAN DI ERA MILENIAL (STUDI KASUS LOKA LATIHAN KERJA UKM KABUPATEN BIAK NUMFOR). JURNAL NALAR PENDIDIKAN, 8(24770515), 114-123. https://doi.org/10.26858/jnp.v8i2.15519

Depdiknas, (2002). Kurikulum Berbasis Kompetensi. Jakarta: Balitban Depdiknas

Nurdiana Dhieni, dkk, 2005. Metode Pengembangan Bahasa. Jakarta: Universitas Terbuka

Widyatun Diah, 2012. Model Pembelajaran Role Playing. Bandung: PT. Remaja Rosda Karya.

Hildebrand, 1986. Intraductiun to Early Childhood education. 4th.ed. New York: Mae Millan Publishing Company

John W., Santrock. 2011. Perkembangan Anak Jakarta: Erlangga. Mafrukhi, Sayuti. 2009. Cara melatih Kemampuan Berbicara Anak. http://www.indoskripsi.com/Cara-Melatih-KemampuanBerbicara-Anak (diakses pada tanggal 5 Januari 2020)

Masitoh, dkk. 2006. Strategi Pembelajaran TK. Jakarta: Universitas Terbuka.

Moeslichatoen R. 2004. Metode Pengajaran di Taman Kanak-Kanak. Jakarta: Rineka Cipta

Nurhadi, 1995. Pembinaan dan Penembangan Bahasa dan Sastra Indonesia. Bandung: UPI PRESS.

Suhartono. 2005. Metode Pengembangan Konitif. Jakarta: Universitas Terbuka

Santoso, Soegeng. 2007. Dasar-Dasar Pendidikan TK. Jakarta: Universitas Terbuka 
Darlin, Samar, Busyairi Ahmad (Penerapan Model Pembelajaran Role Playing)

Sudono, Anggani. 2000. Sumber Belajar dan Alat Permainan untuk Pendidikan Usia Dini. Jakarta:

Grasindo

Sudjana, 2001. Metode dan Teknik Pembelajaran Partisipatif. Bandung: Falah Production

Supriyadi, 2005. Pendidikan Bahasa Indonesia 2. Jakarta: Depdikbud.

Saroji, 2014. Perkembangan Bahasa Anak (http://blokspot.com). (diakses pada

tanggal 5 Januari 2020)

Tarigan, Djago, dkk, 2008. Pengembangan Keterampilan Berbicara. Jakarta: Depdikbud.

Tim Proyek, PGSM, 1990. Penelitian Tindakan Kelas (Bahan Penelitian Dosen LPTK dan Guru Sekolah Menengah). Jakarta: Depdikbud.

Muliyati Yeti, 2007. Modul: Keterampilan Berbahasa Indonesia SD. Jakarta: Universitas Terbuka.

ZamZani, 2012. Peningkatan Keterampilan Berbahasa. Bandung: PT. Remaja Rosda Karya.

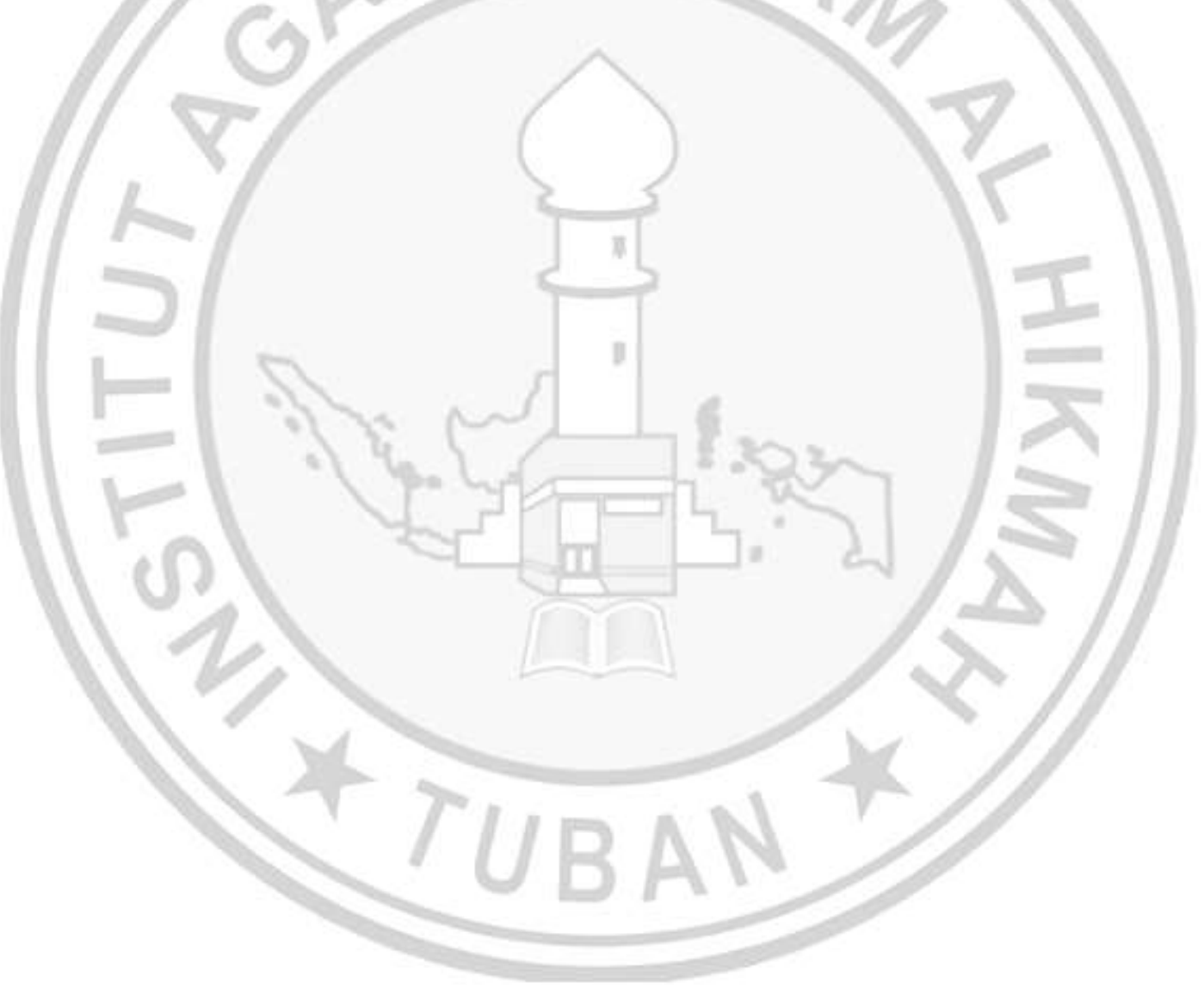

